\title{
Relationship between Some Physiological Characters and Yield of Heat-Toler- ant, Non-Tolerant, and Tropical Tomato Cultivars Grown at High Temperature
}

\author{
George Oduro Nkansah and Tadashi Ito \\ Faculty of Horticulture, Chiba University, Matsudo, Chiba 271
}

\begin{abstract}
Summary
The relationships between physiological characters; photosynthesis $\left(\mathrm{P}_{\mathrm{r}}\right)$, transpiration (E), stomatal conductance $\left(G_{s}\right)$, and yield of three heat-tolerant tomato (Lycopersicon esculentum Mill.) crs. Shikiaka. Shuki and Ohio 7663, non heat-tolerant cv. Sataan; and two tropical cvs. Owusu-Bioh and Wosowoso, grown at $40^{\circ} / 23^{\circ} \mathrm{C}$ day/night temperatures were examined.

Physiological characters were measured at air temperatures of $20^{\circ}, 30^{\circ}$, and $40^{\circ} \mathrm{C} \cdot \mathrm{Pr}_{\mathrm{r}}$ for heat-tolerant cultivars pooled at the seedling stage $(5 \sim 7$ leaves) was significantly greater than non heat-tolerant cultivars at $20^{\circ}$ and $40^{\circ} \mathrm{C} . \mathrm{P}_{\mathrm{r}}, \mathrm{E}$, and $\mathrm{G}_{\mathrm{s}}$ at the flowering and early fruit development stage $(13-15$ leaves) were significantly higher in the heattolerant cultivars compared to the other cultivars at all temperatures. $P_{r}$ at the seedling stage did not significantly correlate with yield but $P_{r}, E$ and $G_{x}$ were significantly correlated with fruit yield at the flowering and early fruit development stage. A linear relationship between $P_{r}$ and $G_{s}$ and between $E$ and $G_{s}$ revealed a close and significant consequential relationship between $E$ and $P_{r}$. Regressions among physiological variables were not homogenous among/between cultivars. Regressions between $P_{r}, E, G_{s}$, and yield were heterogenous among/between cultivars. Heat-tolerant cultivars had greater yields than the other cultivars. The results indicate that yield significantly and positively correlated with $P_{r}$, E, and $G_{s}$.
\end{abstract}

\section{Introduction}

Physiological characters such as photosynthesis. transpiration and stomatal conductance affect growth and yield in crop plants. Photosynthesis ultimately limits crop productivity. however, its exact relationship with yield is unclear. Correlations between yield and photosynthesis are often inconsistent and not significant (Curtis et al. 1969; Evans, 1976; Gay et al.. 1980; Peet et al.. 1977). Wong et al. (1979) observed that stomatal conductance correlated with photosynthetic activ. ity. The exact relationship between transpiration or stomatal conductance and yield in heat-tolerant and non heat-tolerant tomatoes are also not well defined.

The effect of high temperature on plant growth and yield through effects on these physiological characters in tomatoes cannot be over-emphasized.

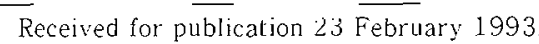

At temperatures of about $30^{\circ} \sim 35^{\circ} \mathrm{C}$, heat-tolerant tomatoes had higher photosynthetic rate than sensitive cultivars (Bar-Tsur et al., 1985a). Transpiration is temperature dependent (Berry and Bjorkman, 1980) and leaf temperature effect on stomatal conductance has been reported for a number of plant species (Schulze et al., 1974).

The cultivation of heat-tolerant tomatoes in many tropical and summer areas is indispensable hence the relationship between photosynthesis, transpiration, stomatal conductance and yield in heat-tolerant tomatoes is deemed important.

The objective of this study was to evaluate the relationships between physiological characters especially photosynthesis, transpiration, stomatal conductance and yield in six tomato cultivars grown at high temperatures.

\section{Materials and Methods}

Six cultivars of tomato which differed in sensi. tivity to high temperature were used (Table 1). 
Table 1. Tomato cultivars used in this experiment.

\begin{tabular}{|c|c|c|}
\hline Cultivar & Heat susceptibility & Source \\
\hline Shikiaka & $\mathrm{HT}^{2}$ & Known You Seed Company. Taiwan \\
\hline Shuki & $\mathrm{HT}$ & Known You Seed Company, Taiwan \\
\hline Ohio 7663 & $\mathrm{HT}$ & Agric. Res. and Devpt. Center. Ohio, USA \\
\hline Owusu-Bioh & $\mathrm{NT}^{y}$ & Crop Science Dept.. Univ. of Ghana. Ghana \\
\hline Wosowoso & NT & Crop Science Dept.. Univ. of Ghana, Ghana \\
\hline Sataan & NT & Takii Seed Company, Japan \\
\hline
\end{tabular}

Table 2. Yield and yield attributes of six tomato cultivars.

\begin{tabular}{|c|c|c|c|c|c|}
\hline \multirow[b]{2}{*}{ Cultivar } & \multirow[b]{2}{*}{$\begin{array}{l}\text { Growth } \\
\text { habit }\end{array}$} & \multirow[b]{2}{*}{$\begin{array}{l}\text { Yield } \\
\text { t. ha }^{-1}\end{array}$} & \multicolumn{2}{|c|}{ Yield components } & \multirow[b]{2}{*}{$\begin{array}{l}\text { Fruit size } \\
\mathrm{g} / \text { fruit }\end{array}$} \\
\hline & & & $\begin{array}{c}\text { Fruit set } \\
(\%)\end{array}$ & $\begin{array}{l}\text { Fruit no. } \\
\text { no./plant }\end{array}$ & \\
\hline Shikiaka & $D^{y}$ & $20.33 \mathrm{~d}^{z}$ & $56.3 c$ & $90.1 \mathrm{c}$ & $11.2 \mathrm{a}$ \\
\hline Shuki & I & $12.83 \mathrm{c}$ & $33.3 \mathrm{~b}$ & $42.6 \mathrm{~b}$ & $15.1 \mathrm{ab}$ \\
\hline Ohio 7663 & D & $5.97 \mathrm{~b}$ & $22.9 \mathrm{ab}$ & $5.6 \mathrm{a}$ & $53.6 b c$ \\
\hline Sataan & I & $2.30 \mathrm{a}$ & $7.4 \mathrm{a}$ & $2.0 \mathrm{a}$ & $60.0 \mathrm{c}$ \\
\hline Owusu-Bioh & l & $0.64 \mathrm{a}$ & $3.0 \mathrm{a}$ & $1.1 \mathrm{a}$ & $26.5 \mathrm{abc}$ \\
\hline Wosowoso & $I$ & $1.07 \mathrm{a}$ & $2.7 \mathrm{a}$ & $1.7 \mathrm{a}$ & $28.9 \mathrm{abc}$ \\
\hline
\end{tabular}

Seeds of these cultivars were sown on 4 May, 1990. Seedlings were grown in plastic pots $(500$ $\mathrm{cm}^{3}$ ) containing garden soil.

Seedlings were transplanted into soil in the greenhouse five weeks after seeds were sown. Plants were grown under natural daylight (14 $15 \mathrm{hrs})$ at $40^{\circ} \pm 1^{\circ} \mathrm{C}$ maximum temperature and $23^{\circ} \pm 1^{\circ} \mathrm{C}$ night temperature. Plants were exposed to maximum day temperature during $10: 00$ am to 3:00 pm. On sunny days, photosynthetic active radiation (PAR) increased from $750 \mu \mathrm{mol} \cdot \mathrm{m}^{-2}$. $\mathrm{s}^{-1}$ at $8.30 \mathrm{am}$ to about $1200 \mu \mathrm{mol} \cdot \mathrm{m}^{-2} \cdot \mathrm{s}^{-1}$ around noon before it gradually decreased to about $470 \mu \mathrm{mol} \cdot \mathrm{m}^{-2} \cdot \mathrm{s}^{-1}$ at $16: 30 \mathrm{pm}$. A fertilizer rate of $15: 25: 15 \mathrm{~kg} / 1,000 \mathrm{~m}^{2}(\mathrm{~N}: \mathrm{P}: \mathrm{K})$ and $80 \mathrm{~kg} / 1,000 \mathrm{~m}^{2} \mathrm{CaCO}_{3}$ was applied to the soil. A. randomized complete block design with three replications was used. Each experimental plot consisted of seven plants per cultivar with a spacing of $110 \mathrm{~cm} \times 45 \mathrm{~cm}$ per plant. The inner five plants per treatment per plot were used for data collection hence 15 plants per variable were measured.

At the 5 -7 leaf stage, five weeks after sowing, photosynthetic rate was measured in an assimila- tion chamber using an infra-red gas analyzer (Shimadzu, URAS-2) as described by Ito (1971). Four plants/cultivar were used for each temperature treatment. Temperatures used for measurements in the chamber were $20^{\circ}, 30^{\circ}$, and $40^{\circ} \mathrm{C}$. Air flow rate was controlled at 7 liters $\cdot \min { }^{-1}$. Light source was high pressure sodium lamps of $420 \mu$ $\mathrm{mol} \cdot \mathrm{m}^{-2} \cdot \mathrm{s}^{-1}$ photosynthetic photon flux density.

Leaf photosynthesis, transpiration, and stomatal conductance during flowering and early fruit development stage (13 15 leaves) were measured in the greenhouse with the use of a portable porometer (Kip.8510 Ver. 2.03, Koito Industries). A fully expanded, matured, and attached second or third leaf from the apex was used for measurement. Temperatures used for phyiological measurements were the same as those used in growth chamber.

Pollination was carreid out by means of wire vibration and no plant growth regulator was used for fruit set. Fruit number and fruit weight $(\mathrm{kg})$ per plant per cultivar were calculated, at each harvest. Harvesting lasted for three months. Plants were topped at the seventh truss where the deter. minate cultivars terminated flowering. 


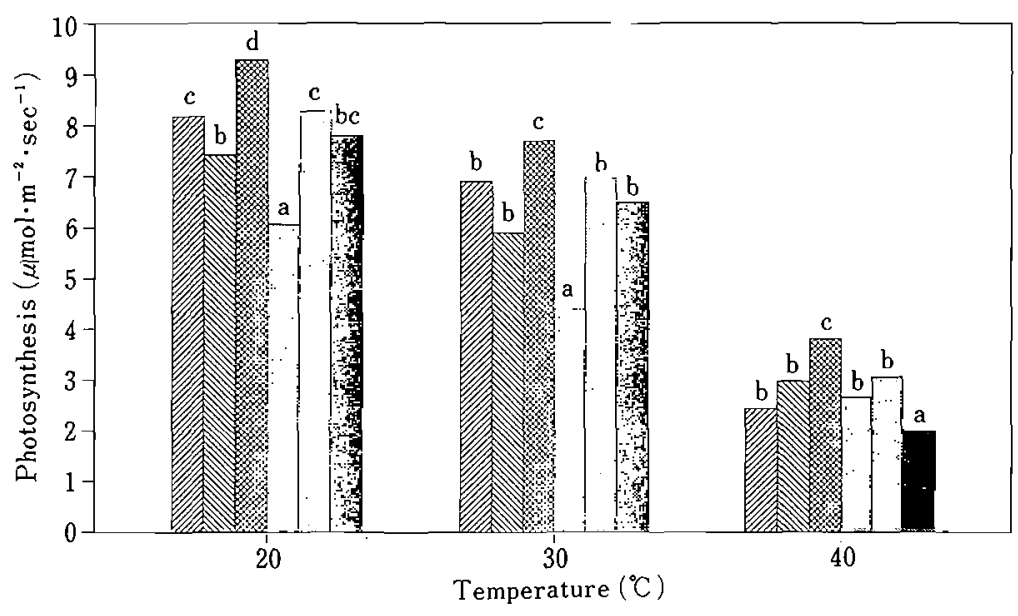

Shikiaka Shuki $\mathbb{Q}$ Ohio 7663 [1Sataan

Fig. 1. Effect of temperature on photosynthesis $\left(\mu \mathrm{mol} \cdot \mathrm{m}^{-2} \cdot \mathrm{sec}^{-1}\right)$ of six tomato cultivars at the seedling stage. Same letters within each measured temperature among cultivars are not significantly different by Duncan's new multiple range test, $\mathrm{P}=0.05$.

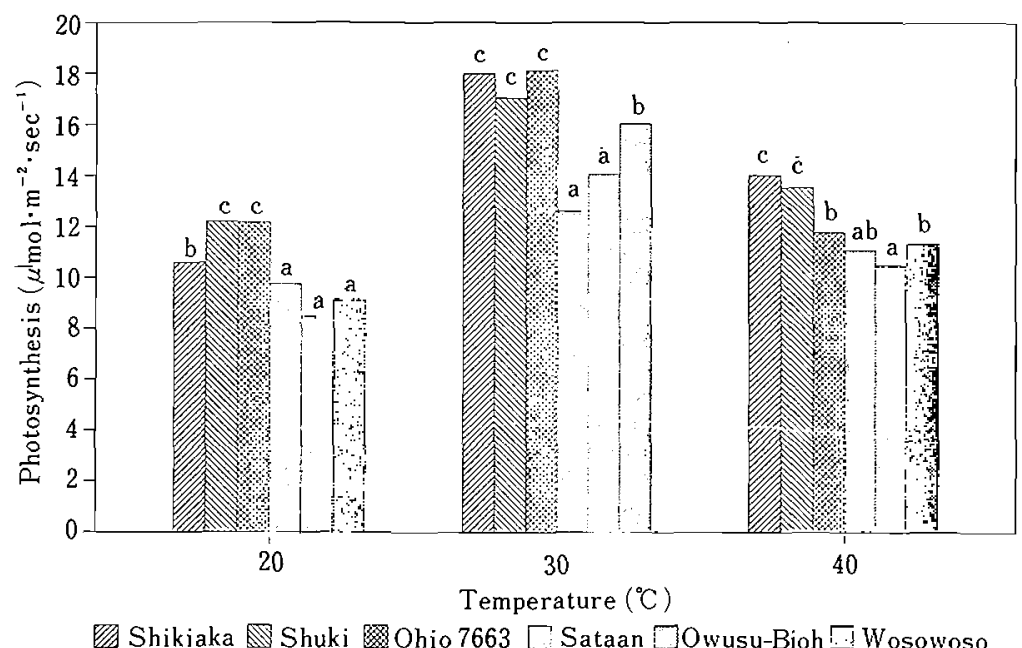

Fig. 2. Effect of temperature on photosynthesis $\left(\mu \mathrm{mol} \cdot \mathrm{m}^{-2} \cdot \mathrm{sec}^{-1}\right)$ of $\operatorname{six}$ tomato cultivars at the flowering and early fruit development stage. Same letters with in each measured temperature among cultivars are not significantly different by Duncan's new multiple range test. $\mathrm{P}=0.05$.

The data were analyzed using analysis of variance procedure and means were separated at $P$ $=0.05$ by Duncan's new multiple range and the paired T-tests. The relationship between yield and physiological characters $\left(P_{r}, E, G_{s}\right)$ were described with linear regression analysis. Homogeneity of regressions to compare slopes between physiological variables and yield among cultivars were evaluated using a technique outlined by Gomez and Gomez (1984). Since slopes between the tropical 
and non heat-tolerant were homogeneous, they were classified as conventional cultivars.

Table 3. Effect of temperature on photosynthesis $(\mathrm{Pr})$. transpiration (E). and stomatal conductance $(G s$ ) of tomatoes.

\begin{tabular}{|c|c|c|c|}
\hline & & Temperature $\left({ }^{\circ} \mathrm{C}\right)$ & \\
\hline Cultivar & 20 & 30 & 40 \\
\hline \multicolumn{4}{|c|}{$\left.\operatorname{Pr}: \mu \mathrm{mol} \cdot \mathrm{m}^{2} \cdot \mathrm{sec}^{-1}\right)$ at seedling stage } \\
\hline Heat-tolerant & 8.30 & 6.84 & 3.09 \\
\hline Conventional & 7.39 & 5.99 & 2.60 \\
\hline Paired $T \cdot$ test $^{2}$ & * & NS & * \\
\hline \multicolumn{4}{|c|}{$\operatorname{Pr}\left(\mu \mathrm{mol} \cdot \mathrm{m}^{-2} \cdot \mathrm{sec}^{-1}\right)$ at flowering and early fruiting stage } \\
\hline Heat-tolerant & 11.65 & 17.73 & 13.12 \\
\hline Conventional & 9.26 & 13.91 & 11.00 \\
\hline Paired T-test ${ }^{2}$ & $* * * *$ & $* * *$ & $* * *$ \\
\hline \multicolumn{4}{|c|}{$\mathrm{E}\left(\mathrm{m} m \mathrm{ol} \cdot \mathrm{m}^{-2} \cdot \mathrm{sec}^{-1}\right)$ at flowering and early fruiting stage } \\
\hline Heat-toierant & 0.79 & 2.91 & 3.95 \\
\hline Conventional & 0.64 & 2.41 & 3.29 \\
\hline Paired $\mathrm{T}$-test ${ }^{x}$ & $* *$ & $*$ & $*$ \\
\hline \multicolumn{4}{|c|}{$G s\left(\mathrm{~cm} \cdot \sec ^{-1}\right)$ at flowering and early fruiting stage } \\
\hline Heat.tolerant & 0.15 & 0.35 & 0.30 \\
\hline Conventional & 0.13 & 0.30 & 0.20 \\
\hline Paired T-test ${ }^{z}$ & $*$ & $* *$ & $* *$ \\
\hline
\end{tabular}

\section{Results}

Yield and yield components

Results in Table 2 indicate that, 'Shikiaka' had the highest yield, fruit set, and number followed by 'Shuki' and 'Ohio 7663'. The heat-tolerant cultivars, 'Shikiaka', 'Shuki' and 'Ohio 7663' differed significantly from the conventional cultivars in terms of yield and percent fruit set.

Photosynthesis, transpiration, and stamatal conductance response to temperature

Photosynthetic rate $\left(\mathrm{P}_{\mathrm{r}}\right)$ at the seedling stage $(5$ $\sim 7$ leaves) decreased from $20^{\circ}$ to $40^{\circ} \mathrm{C}$ (Fig. 1 and Table 3 ). Heat-tolerant cultivars showed higher. $\mathrm{P}_{\mathrm{r}}$ at $20^{\circ}$ and $40^{\circ} \mathrm{C} . \mathrm{P}_{\mathrm{r}}$ varied significantly among the cultivars. 'Ohio 7663' had the highest $\mathrm{P}_{\mathrm{r}}$ at all temperatures and 'Sataan' had the lowest at $20^{\circ}$ and $30^{\circ} \mathrm{C}$, and 'Wosowoso' the lowest at $40^{\circ} \mathrm{C}$.

At the flowering and early fruit development stage $\left(13 \sim 15\right.$ leaves), $P_{r}$ in all cultivars increased from $20^{\circ}$ to $30^{\circ} \mathrm{C}$ and declined at $40^{\circ} \mathrm{C}$ (Fig. 2 and Table 3 ). Transpiration rate (E) increased as temperature was increased from $20^{\circ}$ to $40^{\circ} \mathrm{C}$ (Fig. 3 and Table 3 ) while stomatal conductance $\left(G_{s}\right)$ decreased at $40^{\circ} \mathrm{C}$ (Fig. 4 and Table 3 ). Results in

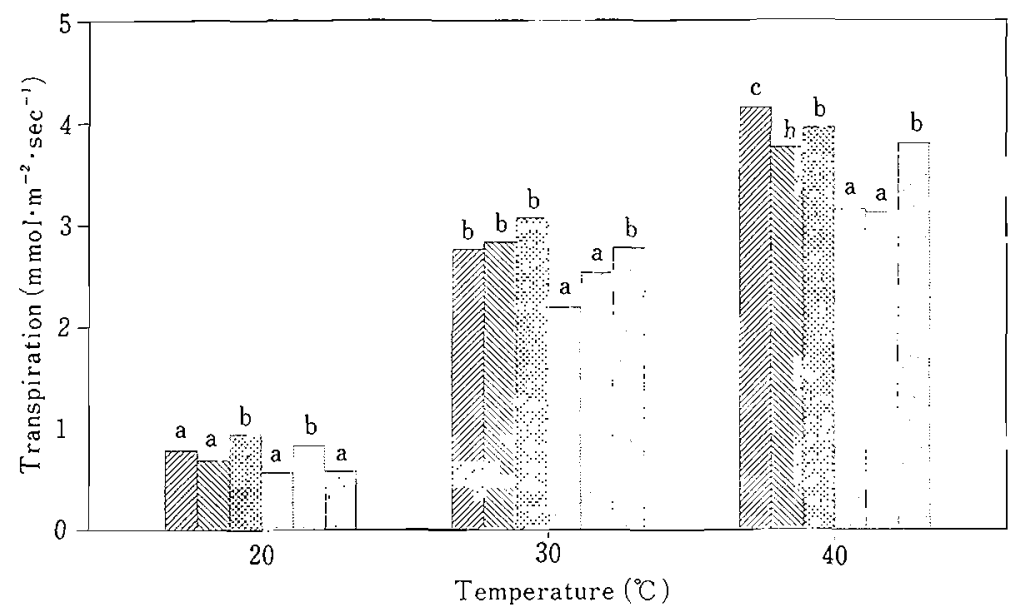

Shikiaka Shuki Ohio 7663 Sataan Owusu-Bioh Wosowoso

Fig. 3. Effect of temperature on transpiration $\left(\mathrm{mmol} \cdot \mathrm{m}^{-2} \cdot \mathrm{sec}^{-1}\right)$ of $\mathrm{six}$ tomato cultivars at the flowering and early fruit development stage. Same letters with in each measured temperature among cultivars are not significantly different by Duncan's new multiple range test. $\mathrm{P}=0.05$. 


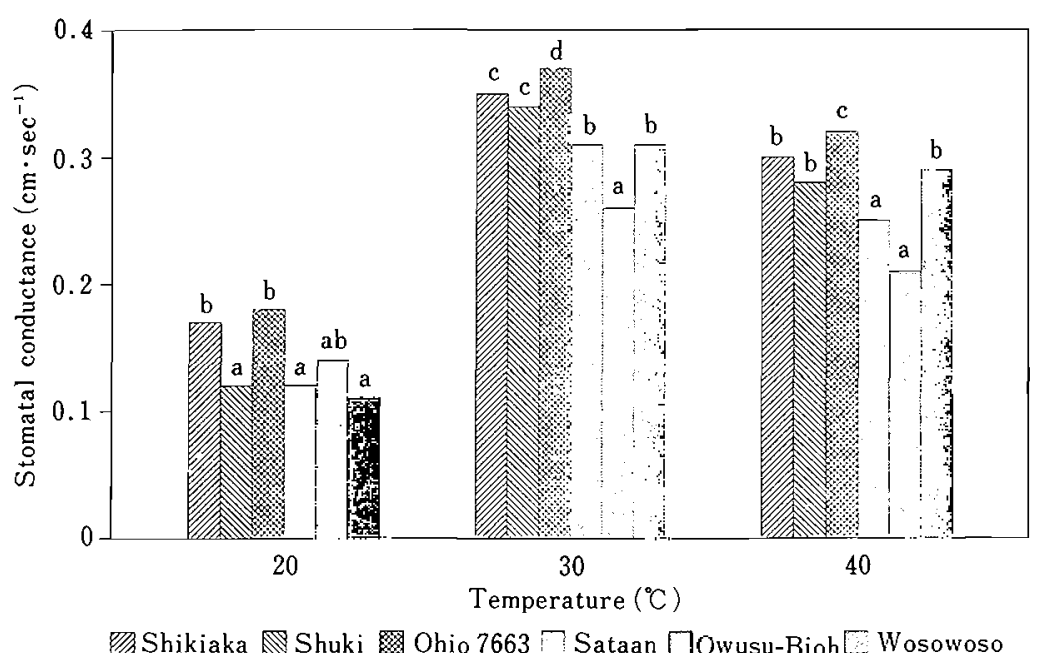

Fig. 4. Effect of temperature on stomatal conductance $\left(\mathrm{cm} \cdot \mathrm{sec}^{-1}\right.$ ) of six tomato cultivars at the flowering and early fruit development stage. Same letters within each measured temperature among cultivars are not significantly different by Duncan's new multiple range test. $\mathrm{P}=0.05$.

Figure 2 indicate that, at the flowering and initial fruit development stage, $P_{r}$ of 'Shikiaka', 'Shuki', and 'Ohio 7663' were greater than that of the conventional cultivars at $20^{\circ}$ and $30^{\circ} \mathrm{C}$. At $40^{\circ} \mathrm{C}$ 'Ohio 7663' did not differ from 'Wosowoso' and 'Sataan' although its $\mathrm{P}_{\mathrm{r}}$ value was numerically higher.

Cultivar and temperature effects on $E$ and $G_{s}$ measured at the flowering and early fruit development stage differed among cultivars (Figs. 3 and 4). At $20{ }^{\circ} \mathrm{C}, \mathrm{E}$ for 'Owusu-Bioh' did not differ from the heat-tolerant lines while at $30^{\circ} \mathrm{C}$ and $40^{\circ} \mathrm{C}, \mathrm{E}$ was greater in all the heat-tolerant cultivars compared to 'Owusu-Bioh' and 'Sataan' (Fig. $3) . G_{s}$ at $20^{\circ} \mathrm{C}$ was greater for two of the heattolerant cultivars, 'Shikiaka' and 'Ohio 7663'. At $30^{\circ} \mathrm{C}, \mathrm{G}_{\mathrm{s}}$ was greater in all the heat-tolerant cultivars compared to the other cultivars, but at $40^{\circ} \mathrm{C}$. 'Wosowoso' did not differ from two of the heat-tolerant lines, 'Shikiaka' and 'Shuki' (Fig. 4).

When physiological characters for all heat-tolerant cultivars were pooled and compared to the conventional cultivars (Table 3 ), $P_{r}$ of the former was significantly higher than the latter at $20^{\circ} \mathrm{C}$ and $40{ }^{\circ} \mathrm{C}$ at the seedling stage. At the flowering and fruit development stage, $P_{r}, E$, and $G_{S}$ of the heat-tolerant cultivars were higher than the conventional cultivars at all temperatures.
Relationship between physiological characters and Yield

Correlations of $P_{r}, E$, and $G_{s}$ on yield at the flowering and early fruit development stage were significant at all three temperature levels but only results at $40^{\circ} \mathrm{C}$ are presented (Table 4). Correlations for $\mathrm{P}_{\mathbf{r}}$ on yield at the seedling stage was nonsignificant (data not shown). Yield correlated significantly with photosynthesis at the flowering and early fruit development stage (Table 4). There was a significant positive relationship between yield and $E$ as well as with $G_{s}$ among cultivars (Table 4).

Results in Table 4 also indicate that, $G_{\mathrm{S}}(\mathrm{X})$ and $\operatorname{Pr}(Y)$, and $G_{s}(X)$ and $E(Y)$ were correlated among cultivars. The correlation between $G_{s}$ and $P_{r}$ or $E$ resulted in a consequential close and significant relationship between $\mathrm{E}(\mathrm{X})$ and $\mathrm{P}_{\mathrm{r}}(\mathrm{Y})$.

Heterogeneity in regression coefficients was observed between the heat-tolerant and conventional cultivars except $\mathrm{E}$ on yield at $40^{\circ} \mathrm{C}$. The increase in yield due to $P_{r}$ and $G_{s}$ was greater in the former than in the latter cultivar (Table 5 ).

Regressions among $P_{r}, E$, and $G_{s}$ were heterogeneous between heat-tolerant and conventional cultivars at the measured temperatures (Table 5). Slopes were greater in the former than the latter 
at $20^{\circ}$ and $30^{\circ} \mathrm{C}$ but, at $40^{\circ} \mathrm{C}, G_{s}$ on $P_{r}$ or $E$ was greater for the conventional cultivars (Table 5 ).

\section{Discussion}

Photosynthesis, transpiration, and stomatal conductance were affected by high temperature. The decrease in photosynthesis at $40^{\circ} \mathrm{C}$ may be due to enzyme inhibition and increased resistance to $\mathrm{CO}_{2}$ diffusion from the outside air to the chloroplast as a result of partial stomatal closure.

The lower photosynthetic activity in young tomato plants ( $5-7$ leaves) may be attributed to a

Table 4. Regression equations and correlations between yield and photosynthesis ( $\mathrm{Pr}$ ), transpiration (E). stomatal conductance (Gs), and fruit set (FS) and the relations among physiological characters measured at $40^{\circ} \mathrm{C}$ at the flowering and early fruit development stage of six tomato cultivars.

\begin{tabular}{|c|c|c|c|}
\hline Variable & Equation & $\mathrm{R}$ & $\mathrm{R}^{2}$ \\
\hline Pr on Yield & $\mathrm{Y}=-57.66+5.39 \mathrm{X}$ & $0.95 * * *^{2}$ & 0.90 \\
\hline E on Yield & $Y=-40.49+13.05 X$ & $0.69 * * *$ & 0.48 \\
\hline Gs on Yield & $Y=-19.65+97.64 X$ & $0.48 * * *$ & 0.23 \\
\hline FS on Yield & $Y=-0.51+0.37 X$ & $0.95 * * *$ & 0.90 \\
\hline \multicolumn{4}{|c|}{ Relationship among physiological variables } \\
\hline Gs on $\operatorname{Pr}$ & $\mathrm{Y}=6.33+20.76 \mathrm{X}$ & $0.49 * * *$ & 0.24 \\
\hline Gs on $E$ & $Y=0.93+9.90 X$ & $0.72 * * *$ & 0.51 \\
\hline Eon $\mathrm{Pr}$ & $Y=2.76+2.54 X$ & $0.63 * * *$ & 0.41 \\
\hline
\end{tabular}

photosynthetic system that may not yet be completely developed, high rates of dark respiration (Valanne et al., 1981) and low stomatal and intracellular conductances for $\mathrm{CO}_{2}$ transfer.

The higher rate of photosynthetic activity of leaves at the flowering and early fruit development stage $(13 \sim 15$ leaves) compared to those of leaves at the seedling stage indicate that, the presence of flowers and fruits positively stimulates the photosynthetic activity of leaves, probably by enhancing the rate at which the products of photosynthesis are translocated from the production sites. This agrees with the works of Maggs (1963) and Hall and Brady (1977) who observed that the presence of fruits enhances the photosynthetic activity of leaves.

The higher photosynthetic rate for the heattolerant cultivars compared to the conventional cultivars at the seedling and the flowering and early fruit development stages (Table 3 ) may be due to their different physiological trait such as an efficient photosynthetic apparatus and wider stomatal opening which contribute to their tolerance especially at high temperatures. Bar. Tsur et al. (1985a) reported higher photosynthetic activity for heat-tolerant cultivars than for sensitive ones.

The lower transpiration rates at $20^{\circ} \mathrm{C}$ indicated the possibility of increased resistance to water flow into and through the plant (Fig. 3). The data also indicate that temperature may reduce photosynthesis while stomata are still open. Thus an in crease in transpiration but a decrease in photo-

Table 5. Regression coefficients between yield (Yd) and physiological characters and anong physiological characters of tomato cultivars at the flowering and early fruit development stage. Slopes were evaluated using a technique outlined by Gomez and Gomez (1984).

\begin{tabular}{|c|c|c|c|c|c|c|c|}
\hline $\begin{array}{c}\text { Temperature } \\
\left({ }^{\circ} \mathrm{C}\right)\end{array}$ & Cultivar & $\mathrm{Yd}$ and $\mathrm{Pr}$ & $\mathrm{Yd}$ and $\mathrm{E}$ & $\mathrm{Yd}$ and $\mathrm{Gs}$ & $\begin{array}{l}\text { E and } \operatorname{Pr} \\
\left(\times 10^{-2}\right)\end{array}$ & $\begin{array}{l}\text { Gs and } \mathrm{Pr} \\
\left(\times 10^{-2}\right)\end{array}$ & $\begin{array}{l}\text { Gs and } \mathrm{E} \\
\left(\times 10^{-2}\right)\end{array}$ \\
\hline \multirow[t]{2}{*}{20} & $\mathrm{HT}^{y}$ & 1.96 & 19.25 & 78.34 & 10.20 & 2.51 & 24.60 \\
\hline & $C C^{x}$ & 0.94 & 11.72 & 47.50 & 8.10 & 1.97 & 24.50 \\
\hline Sign ificance ${ }^{z}$ & & $* *$ & $* *$ & $* *$ & $* *$ & *** & $* *$ \\
\hline \multirow[t]{2}{*}{30} & $\mathrm{HT}^{\mathrm{z}}$ & 2.66 & 5.37 & 53.15 & 50.00 & 5.00 & 10.10 \\
\hline & $C C^{*}$ & 1.21 & 2.31 & 34.04 & 54.60 & 3.70 & 6.90 \\
\hline Significance & & $* *$ & $* *$ & $* *$ & ns & $* *$ & $* *$ \\
\hline \multirow[t]{2}{*}{40} & $\mathrm{HT}^{\mathrm{z}}$ & 1.97 & 4.04 & $53: 45$ & 48.70 & 3.70 & 7.60 \\
\hline & $C C^{y}$ & 0.98 & 4.89 & 23.13 & 20.00 & 4.30 & 21.40 \\
\hline Significance & & $* *$ & NS & $* *$ & $* *$ & $* *$ & $* *$ \\
\hline
\end{tabular}

$z * *$. NS : Signifficant at $1 \%$ and nonsignificant respectively according to t-test with $26 \mathrm{df}$.

$y \quad$ Pooled heat-tolerant culivars.

$x$ Pooled tropical and non-tolerant cultivars. 
synthesis at higher temperatures (Table 3). This agrees with Bar-Tsur et al. (1985b) who observed that, photosynthesis decreased while transpiration increased with temperature up to $39^{\circ} \mathrm{C}$.

The higher transpiration rates of the heat-tolerant cultivars may have some ecological significance concerning tolerance to hot, humid conditions. An increase in stomatal conductance may confer several adaptive advantages. Open stomata would enhance evaporative cooling at high temperatures (Schulze et al., 1973) and high photosynthesis at optimum air temperatures (Al-Ani et al., $1972)$.

The lack of correlation between photosynthesis and yield at the seedling stage may be attributed to an incomplete photosynthetic system (Leopold and Kriedemann, 1975; Sams and Flore, 1982).

The significant and positive correlation between photosynthesis and yield at the flowering and early fruit development stage (Table 4) contrasts ear. lier reports that, correlations between yield and photosynthesis are often inconsistent and not significant (Curtis et al., 1969; Evans, 1976; Gay et al., 1980; Peet et al., 1977). The reason may be attributed to the no significant differences they observed in $\mathrm{CO}_{2}$ uptake between the high and low yielding soybeans they used. However, we found significant differences in photosynthesis between the heat-tolerant and conventional tomato cultivars (Table 3 ).

The correlation between stomatal conductance and photosynthesis or transpiration which resulted in a consequential close and significant relationship between transpiration and photosynthesis (Table 4) agrees with other reports (Hamid et al., 1990; Raschke, 1975).

The higher regression coefficients of the heattolerant cultivars compared to the conventional ones when photosynthesis was regressed on yield indicates that, higher yields were associated with higher photosynthesis in the former cultivars. Fruit set correlated significantly with yield (Table 4). Yield variation was partly due to percentage fruit set. Fruit set was much better in the heattolerant cultivars than in the conventional ones at high temperatures. The evidence that the heattolerant cultivars are better adapted to high temperature indicates a possible linkage between fruit set and continued photosynthesis at high temperatures.
In this experiment, we found that yield correlated significantly and possitively with photo. synthesis, transpiration and stomatal conductance. Higher photosynthetic activity, transpiration, stomatal conductance, fruit set and yield were associated with the heat-tolerant cultivars compared to the conventional ones. In view of these findings, we may recommend these heat-tolerant cultivars for tomato cultivation in the hot humid tropics and areas with high summer temperature conditions. These cultivars also provide opportunities as genetic materials for breeding more heat-tolerant cultivars adapted to high temperature stress conditions for further increases in productivity. They may as well be important in physiological and biochemical studies concerning the molecular basis of heat tolerance.

\section{Acknowledgement}

Our gratitude to S. Berry (Ohio State University, Ohio, U.S.A.), for the seeds of 'Ohio 7663', and Known-You Seed Co. Ltd. (Taiwan) for the seeds of 'Shuki' and 'Shikiaka'. We also thank T. Maruo for his technical assistance. Financial support by the Ministry of Education, Science and Culture of Japan is greatfully acknowledged.

\section{Literature Cited}

Al-Ani, H. A., B. R. Strain and H. A. Mooney. 1972 The physiological ecology of diverse populations of the desert shrub Simmondsia chinensis. Ecology $60: 41-57$.

Bar-Tsur, A., J. Rudich and B. Bravdo. 1985a. High temprature effect on gas exchange in heat-tolerant and sensitive tomatoes. J. Amer. Soc. Hort. Sci. $110: 582-586$

Bar-Tsur, A., J. Rudich and B. Bravdo. 1985b. Photosynthesis, transpiration and stomatal resistance to gas exchange in tomato plants under high temperature. J. Hort. Sci. $60:$ 405-410.

Barry, J. and O. Bjorkman. 1980. Photosynthetic re sponse and adaptation to temperature in higher plants. Ann. Rev. Plant Physiol. 31 : 491-543.

Curtis, P. E., W. L. Ogren and R. H. Hageman. 1969. Varietal effects in soybean photosynthesis and photorespiration. Crop Science $9: 323-327$.

Evans, L. T. 1976. Crop physiology: some case histo. ries. Cambridge University Press, London.

Gay, S., D. B. Egli and D. A. Reicosky. 1980. Physiological aspects of yield improvement in soybeans. Agronomy J. $72: 387-391$.

Gomez, A. K. and A. A. Gomez. 1984. Statistical Proce dures for Agricultural Research. John Wiley and 
Sons, New York.

Hall, A. J. and C. J. Brady. 1977. Assimilate sourcesink relationships in Capsicum annum L. II. Effects of fruiting and defoliation on the photosynthetic capacity and senescence of leaves. Aust. J. Plant Physiol, 4 : 771-783.

Hamid, A., W. Agata and Y. Kawamitsu. 1990. Photosynthesis, transpiration and water use efficiency in four cultivars of mungbean, Vigna radiata (L.) Wilczek. Photosynthetica 24:96-101.

Ito, T. 1971. Photosynthetic activity of vegetable plants and its horticultural significance. I. Examination of methods in measuring the photosynthesis with assimilation chamber. J. Japan. Soc. Hort. Sci. $40: 35-40$.

Leopold, A. C. and P. E. Kriedemann. 1975. Plant growth and development. 2nd ed. MacGraw-Hill, New York.

Maggs, D. H. 1963. The reduction in growth of apple trees brought about by fruiting. J. Hort. Sci. 38 : 119-128.

Peet, M. M., A. Bravo. D. H. Wallace and J. L. Osbun. 1977. Photosynthesis, stomatal resistance, and enzyme activities in relation to yield of field-grown dry bean varieties. Crop Science $17: 287-293$.
Raschke, K. 1975. Stomatal Action. Ann. Rev. Plant Physiol. $26: 309-340$.

Sams, C. E. and J. A. Flore. 1982. The influence of age, position and environmental variables on net photosynthetic rate of sour cherry leaves. J. Amer. Soc. Hort. Sci. 107 : 339-344.

Schulze, E. D., O. L. Lange, L. Kappen, U. Buschom and M. Evenari. 1973. Stomatal responses to changes in temperature at increasing water stress. Planta $110: 29-42$.

Schulze, E. D., O. L. Lange, M. Evanari, L. Kappen and U. Buschom. 1974. The role of air humidity and leaf temperature in controlling stomatal resistance of Pnunus armeniaca L. under desert conditions. I. A simulation of the daily course of stomatal resistance. Oecologia $17: 159-170$.

Valanne, N., T. Valanne, H. Niemi and E. M. Aro. 1981. The development of the photosynthetic apparatus during leaf opening in silver birch $(B e$ tula pendula Roth.). p. 397-406. In: A koyunoglou, G. (ed.): Photosynthesis Vol. V.

Wong. S. C., I. R. Cowan and G. D. Farquhar. 1979. Stomatal conductance correlates with photosynthetic capacity. Nature 282:428-426.

高温条件下で生育した耐暑性，非耐暑性ならびに熱带性トマト品種の生理的特性と収量

George Oduro Nkansah · 伊東 正

千葉大学園芸学部 271 千葉県松戸市松戸 648

摘要

耐暑性トマト品種·四季紅', ‘朱喜”, 'Ohio 7663', 非 耐暑性トマト品種“サターン’, ならびに熱带性品種 'Owus-Bioh', 'Wosowoso' 昼温 $40^{\circ} /$ 夜温 $23^{\circ} \mathrm{C}$ で栽 培し, 光合成速度 $\left(P_{r}\right)$, 蒸散速度 $(E)$, 気孔コンダ クタンス $\left(\mathrm{G}_{\mathrm{s}}\right)$, 水利用効率などの生理的特性と収量 との関係を調査した．生理的特性はそれぞれ $20^{\circ}, 30^{\circ}$ ， $40^{\circ} \mathrm{C}$ の条件下で測定した。幼苗期の耐暑性卜マト品 種に㧍ける光合成速度は, 非耐暑性品種に比べ, $20^{\circ}$ と $40^{\circ} \mathrm{C}$ で高かった．開花期および果実肥大初期の $\mathrm{P}_{\mathrm{r}}$, $\mathrm{E}, \mathrm{G}_{\mathrm{s}}$ は，耐暑性品種が他の品種より，すべての温度 条件で高かった，幼苗期の光合成速度と収是との間に は，統計的有意差は認められなかったが，開花期，果
実肥大初期の $P_{r} ， E ， G_{s}$ のそれぞれと収望との間に は，有意な相関関係が認められた， P r と E，ならび に $\mathrm{E} と \mathrm{G}_{\mathrm{s}}$ との間には直線的な相関関係が認められ， その結果, 光合成速度と蒸散速度は高い相関を示した。 生理的特性を示す各数值間の回㷌式は, 品種により異

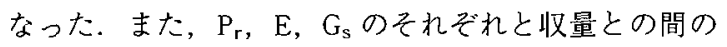
回帰式も，品種間で一定ではなかった。耐暑性卜マト 品種は他の品種に比べて高温条件下で高い収量を得る ことができた，以上の結果，収量と光合成，蒸散速度， および気孔コンダクタンスとの間には，統計的に有意 な正の相関関係が存在することが明らかとなった。 